\title{
Body size versus gonad maturation form in under-yearling precocious males of the sea trout (Salmo trutta m. trutta L.)
}

\author{
Katarzyna DZIEWULSKA*, Józef DomaGAŁA \\ Department of General Zoology, University of Szczecin, 3c Felczaka Street, 71-412 Szczecin, Poland
}

(Received 5 December 2005; accepted 12 July 2006)

\begin{abstract}
The study was aimed at analysing body size in relation to form of gonad maturation (amount of mature germ cells) in 329 under-yearling sea trout males. The fish, aged 7 months, were caught in late October-early November in 3 streams located in north-western Poland. Each stream supported fish belonging to a different sib group. Standard histological techniques and a computer image analysis programme were used to detect the class of gonad maturation and percentage of the gonad area occupied by tubules with active spermatogenesis. Gonad maturation forms were distinguished based on the latter criteria. Gonads with developing germ cells occupying less than $90 \%$ of gonad area were classified as incomplete forms of gonad maturation, others as complete maturation forms. In each sib-groups analysed, even the smallest individual were already precocious, their gonads being incompletely mature. The smallest maturing male measured $7.1 \mathrm{~cm}$ in length. The average size of an incompletely maturing individual was slightly smaller than that of the completely mature one but the difference lacked statistical significance $(P>0.05)$. The sib-group of smaller fish contained less precocious, and the gonads of the more precocious were incompletely mature, compared to the sib-group of larger fish $(P<0.001)$. It seems that the incomplete form of gonad maturation (defected maturation) occurs at a smaller critical fish size than the complete gonad maturation form. Incomplete maturation is more frequent smaller individuals and possibly in among slow-growing groups of fish.
\end{abstract}

Salmo trutta / testis / precocious / incomplete maturation / partial maturation / attempted maturation

\section{INTRODUCTION}

As indicated by the results of numerous studies, fish body growth rate affects the development of the reproductive system. Sexual differentiation is faster in larger fish [1] and their gonadogenesis is faster as well [2]. According to numerous authors, precocious maturation, common in

\footnotetext{
* Corresponding author:

katarzyna.dziewulska@univ.szczecin.pl
}

salmonid males at the parr stage (juveniles mature prior to their first descent to the sea) occurs in the largest individuals [3-15].

In the opinion of many authors, for precocious maturation to begin, salmonid males have to grow to a certain threshold length. A certain critical body size is also necessary for a fish to adapt to a changed habitat, i.e., to smoltification [16-18]. The critical length necessary to smoltification is higher than that at which maturation begins $[19,20]$. 
In salmonids, different parts of the germ cell were observed to have remained inactive during the reproductive cycle in the gonads of precocious males [2, 20-25]. The gonads features different forms of gonad maturation [26]. This study was aimed at analysing the body length-maturation relationship with reference to the different forms of testis maturation in underyearling precocious sea trout.

\section{MATERIALS AND METHODS}

The 7-month old parr of the sea trout (Salmo trutta morpha trutta L.) examined were harvested in October and November of the same year from the brooks Pniewa, Trawna, and Smerdnica, located in the vicinity of Szczecin (Western Pomerania, Poland). All the streams were monitored. They have class I water quality and comparable food availability, good for salmonids. The streams were not inhibited by salmonid fish before, due to unfavourable conditions downstream such as dams and water pollution by sewage. The streams had been stocked with sea trout swimming larvae (20.7-22.5 $\mathrm{mm}$ total length in each stream) grown out at the Polish Anglers' Association in Goleniów. The fertilised eggs had been obtained by artificial spawning of breeders caught in the Rega River. Each stream had been stocked with larvae bred by a single parental pair. The study involved 176 males from the Pniewa, 67 from Smerdnica, and 86 from Trawna. The fish, after they had been sacrificed and the abdomen opened, were fixed in Bouin fluid. The fish were measured (fork length, longitudo caudalis) to $1 \mathrm{~mm}$ and weighed to $0.1 \mathrm{~g}$; subsequently, the gonads were removed and weighed to $0.05 \mathrm{mg}$. The Fulton condition factor $(\mathrm{CF}=$ $100 \mathrm{WL}_{\mathrm{F}}{ }^{-3}$ where $\mathrm{W}=$ weight of whole fish, $\mathrm{g} ; \mathrm{L}_{\mathrm{F}}=$ fish fork length, $\mathrm{cm}$ ) and the gonadosomatic index $\left(\mathrm{GSI}=100 \mathrm{~W}_{\mathrm{G}} \mathrm{W}^{-1}\right.$ where $\mathrm{W}_{\mathrm{G}}=$ gonad weight, $\mathrm{g} ; \mathrm{W}=$ weight of whole fish, g) were calculated. The fish were divided into length classes (8.0-8.4; 8.5-8.9; 9.0-9.4 cm, etc.).

Histological mounts were made, with the standard paraffin technique, with tissue fragments dissected from mid-length of the larger gonad. The $4 \mu \mathrm{m}$-thick sections were Heidenhain iron haematoxylin-stained and examined under a Jenaval (Zeiss) light microscope. Gonad maturity stage was determined using a 9-point scale developed by Dziewulska and Domagała presented in Table I [26]. Gonad maturity form was assessed from the percentage of the gonad cross-section (c-s) area occupied by the tubule-containing developing cells (cyst from SG B to SZ plus actively dividing SG A). The c-s gonad area and the area occupied by the developing cells were determined from a manually delimited area measured with a Leica QWin computer image analysis programme. The cells allowed to distinguish between attempted maturation (AM; developing cells occupying $<30 \%$ gonad c-s area, Fig. 1a), partial maturation (PM; developing cells occupying $30-90 \%$ gonad c-s area, Fig. 1b), and complete maturation (CM; developing cells occupying more than $90 \%$ gonad c-s area, Fig. 1c). The first two forms were considered incomplete gonad maturation (IM). The details are described in Dziewulska and Domagała [26].

The significance of differences between fish fork length of three sib-groups and of different maturation forms in each sibgroup was tested with the non-parametric Kruskal-Wallis test. A chi-squared test was used to compare the frequencies of precocious males and incomplete maturation in the three sib-groups (table $3 \times 2$ ). When the frequencies were different $(P<0.05)$, a Fisher exact test was applied to test for significant differences between the groups ( 3 tests for $2 \times 2$ tables). The statistical analyses were performed with the STATISTICA programme. 
Table I. Histological observations-based on the gonad maturity scale of precocious salmonid males (SG A, spermatogonia A; SG B, spermatogonia B; SC I, primary spermatocyte; SC II, secondary spermatocyte; SD, spermatid; SZ, spermatozoa).

\begin{tabular}{|c|c|c|c|c|c|c|c|}
\hline \multirow[t]{2}{*}{ Class } & \multicolumn{2}{|c|}{ SG } & \multirow[t]{2}{*}{ SC I } & \multirow[t]{2}{*}{ SC II } & \multirow[t]{2}{*}{ SD } & \multirow[t]{2}{*}{$\mathrm{SZ}$} & \multirow{2}{*}{$\begin{array}{c}\text { Sperma- } \\
\text { tion }\end{array}$} \\
\hline & A & B & & & & & \\
\hline I & + & - & - & - & - & - & - \\
\hline \multicolumn{8}{|l|}{ II } \\
\hline $\mathrm{II}_{\mathrm{N}, \mathrm{A}}{ }^{\mathrm{a}}$ & + & + & - & - & - & - & - \\
\hline III & + & + & + & - & - & - & - \\
\hline IV & + & + & + & + & + & - & - \\
\hline $\mathrm{V}$ & + & + & + & + & + & + & - \\
\hline VI & + & + & + & + & + & + & + \\
\hline VII & + & - & + & + & + & + & + \\
\hline \multicolumn{8}{|l|}{$\mathrm{VIIII}^{\mathrm{b}}$} \\
\hline VIII-I & + & - & $-[+]$ & $-[+]$ & $-[+]$ & + & + \\
\hline VIII-II ${ }_{N, A}$ & + & $*$ & $-[+]$ & $-[+]$ & $-[+]$ & + & + \\
\hline \multicolumn{8}{|l|}{ IX } \\
\hline IX-I & + & - & - & - & - & + & $-\left[^{\wedge}\right]$ \\
\hline IX-II & + & $*$ & - & - & - & + & $-\left[{ }^{\wedge}\right]$ \\
\hline IX-III & + & $*$ & $*$ & - & - & + & $-\left[{ }^{\wedge}\right]$ \\
\hline $\mathrm{AM}$ & + & $+\mathrm{s}$ & $+\mathrm{s}$ & $+\mathrm{s}$ & $+\mathrm{s}$ & $+\mathrm{s}$ & - \\
\hline
\end{tabular}

${ }^{\text {a }}$ Sub-class separation based on the number of spermatogonia divisions.

$\mathrm{II}_{\mathrm{N}}$, 4-cell cyst/s of SG B and number of dividing spermatogonia $<32 \mathrm{~mm}^{-2}$.

$\mathrm{II}_{\mathrm{A}}$, 4- cell cyst/s of SG B and number of dividing spermatogonia $\geq 32 \mathrm{~mm}^{-2}$ or cyst/s containing more than 4 SG B.

${ }^{\mathrm{b}} \mathrm{SZ}$ occupy more than $50 \%$ of gonad cross-section (the percentage of motile spermatozoa, with $50 \%$ as the critical level, is an additional criterion of identifying Classes VIII and IX).

* Cells of the subsequent spermatogenic cycle.

[ ], rare cases: [+], few cysts, covering $<5 \%$ gonad cross-section area [^], sperm in the sperm duct.

$\mathrm{AM}$, attempted maturation, i.e., a particular case of maturation resulting from a low number of cells maturing during the cycle (and one of gonad maturation forms); absence of any uniform cell pattern; spermatozoa do not enter the sperm duct; developing cells occupy up to $30 \%$ gonad cross-section.

$\mathrm{s}$, Cells not always visible in sections.

a, b Reprinted from Aquaculture, 250, 3-4, Dziewulska K., Domagała J. Differentiation of gonad maturation in sibling precocious males of the sea trout (Salmo trutta m. trutta L.) in their first year of life, 2005, 713-725, with permission from Elsevier.

\section{RESULTS}

The males examined in late Octoberearly November showed gonads at various developmental classes. The gonads of most individuals were at Class I and some showed their gonads to be at Class II. The remaining individuals were precocious: their gonads were at Classes III-VIII or showed attempted maturation (AM). The gonads of the Smerdnica fish only were advanced not further than Class V. In the 3 groups studied, early maturation was also revealed in the smallest individuals. In fish 


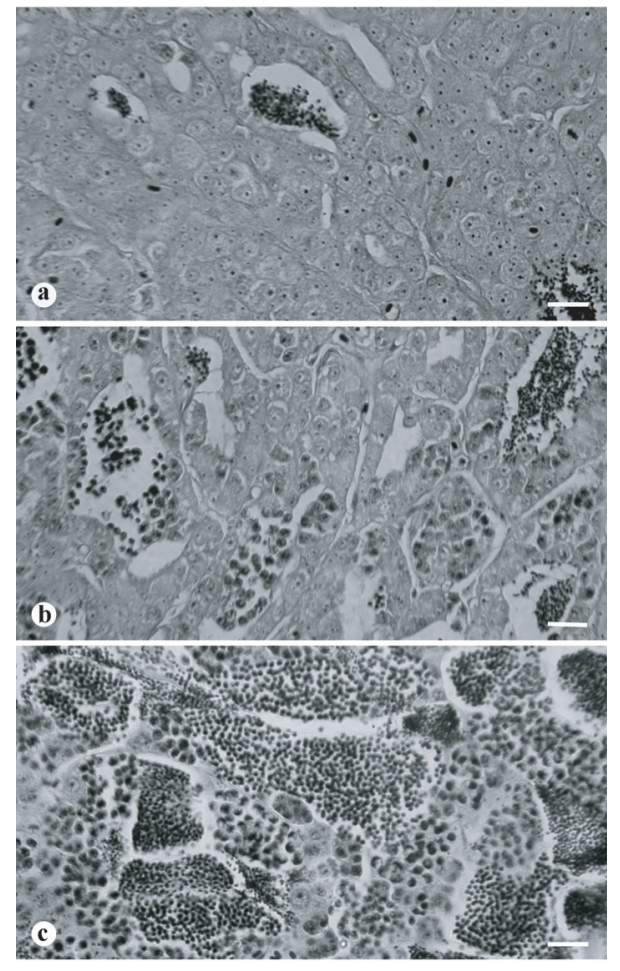

Figure 1. The form of gonad maturation assessed from the percentage of the gonad crosssection (c-s) area occupied by the tubulecontaining developing cells (cyst from SG B to SZ plus actively dividing SG A). (a) Attempted maturation - developing cells occupying $<30 \%$ gonad c-s area; (b) partial maturation - developing cells occupying 30-90\% gonad c-s area; (c) complete maturation - developing cells occupying more than $90 \%$ gonad c-s area. The first two forms were considered as incomplete gonad maturation.

of mean length (FL) 12.3, 11.0 and $10.0 \mathrm{~cm}$ precociously maturing/mature individuals accounted for about 40,32 and $12 \%$, of all the males in the Trawna, Pniewa, and Smerdnica, respectively (Tab. II). Some males at Classes III-VIII featured partial maturation (PM), while others underwent complete gonad maturation (CM).
In the Trawna, the smallest $(9.5 \mathrm{~cm})$ male showed gonads at Class II. The smallest maturing male in the group measured $10.0 \mathrm{~cm}$, had gonads at Class III that revealed PM (developing cells occupied 80\% of the gonad c-s area). Other two males, measuring 10.2 and $10.4 \mathrm{~cm}$, showed AM (developing cells in both males were occupying about $20 \%$ of the gonad c-s area). Gonad tissue mounts of the first revealed spermatogonia B and primary spermatocytes; primary spermatocytes and spermatozoa were visible in mounts of the other male's gonad tissue. The smallest male with complete maturation measured $10.8 \mathrm{~cm}$ and had gonads at Class VII. The gonads of the remaining maturing males were at Classes III-VIII (except for Class VI) and AM. They exhibited the three maturation forms: $\mathrm{AM}, \mathrm{PM}$, and $\mathrm{CM}(17,15$, and $68 \%$ of the maturing males, respectively). The length-frequency distribution of gonad maturation form is shown in Figure 2a. The mean fork lengths were $12.5,12.1$ and $12.6 \mathrm{~cm}$, respectively; the fork length differences were not significant (Kruskal-Wallis test, $P>0.05$ ).

In the Pniewa, the fork length of the smallest maturing male (which was, at the same time, the smallest individual in that sample) was $8.8 \mathrm{~cm}$; the fish had gonads at Class III and revealed PM. Developing cells in the gonads of that individual occupied about $40 \%$ of the gonad c-s area. Another maturing male was slightly larger $(8.9 \mathrm{~cm})$, with few cells at a similar spermatogenesis stage; the developing cells occupied about $20 \%$ of the gonad $\mathrm{c}-\mathrm{s}$ area and the male was classified as AM. The gonads of a slightly larger male $(9.1 \mathrm{~cm})$ were at Class IV and showed $\mathrm{PM}$ as well (the developing cells occupied about $90 \%$ of the gonad c-s area). On the contrary, the smallest male showing $\mathrm{CM}$ measured $9.2 \mathrm{~cm}$ and had gonads at Class VI. Gonads of larger maturing males were at Classes III-VIII and AM. Among the maturing males, the AM, PM, and 





(a)

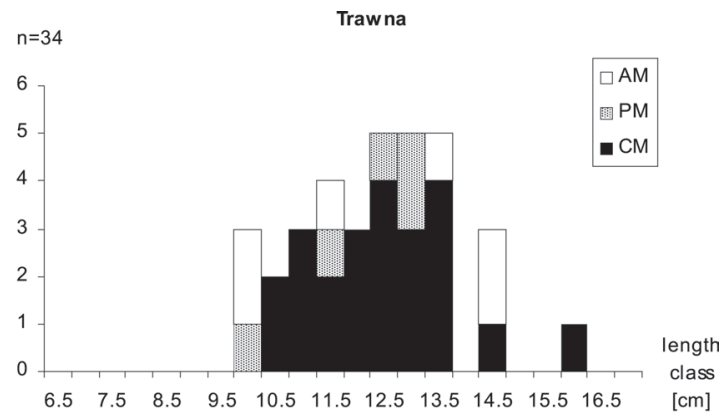

(b)

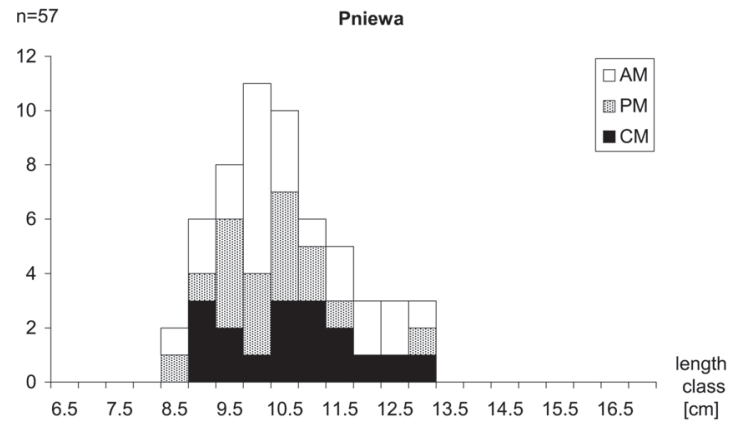

(c)

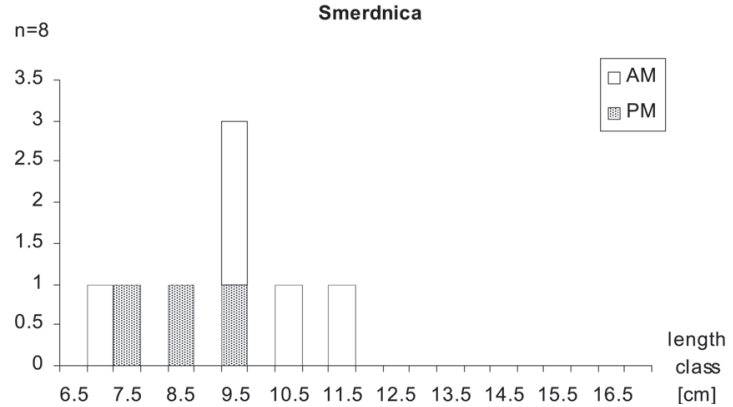

Figure 2. Length-frequency distribution of gonad maturation form in precocious under-yearling males of three sibling sea trout groups. Forms of gonad maturation: AM, attempted maturation; PM, partial maturation; CM, complete maturation, (AM and PM - incomplete maturation).

CM individuals accounted for 40,30 , and $30 \%$, respectively. The length-frequency distribution of gonad maturation form is shown in Figure $2 b$. The mean fork lengths were $10.7,10.5,10.8 \mathrm{~cm}$, respectively; the fork length differences were not significant (Kruskal-Wallis test, $P>0.05$ ).
The gonads of all maturing males in the Smerdnica showed incomplete maturation only. The smallest male measured $7.1 \mathrm{~cm}$ in fork length and matured as AM (developing cells occupied about 20\% of the gonad c-s area and occurred as spermatogonia B and spermatozoa). Another 
male measured $7.9 \mathrm{~cm}$ and had gonads at Class V; the developing cells occupied about $80 \%$ of the gonad c-s area (PM). The gonads of the remaining precocious males in the Smerdnica showed AM or PM and were at Classes III-IV. The AM and PM males accounted for 62 and 38\% of all maturing males, respectively and their respective mean fork lengths were 9.7 and $8.6 \mathrm{~cm}$; the differences were not significant (Kruskal-Wallis test, $P>0.05$ ). The length-frequency distribution of gonad maturation form is shown in Figure 2c.

In the Pniewa and Smerdnica streams the mature males were smaller than immature (10.68 and $11.13 \mathrm{~cm} ; 9.30$ and $10.10 \mathrm{~cm}$, respectively) and were statistically different $(P<0.05)$, while in Trawna they were larger $(12.54$ and $12.22 \mathrm{~cm})$ with no statistical differences $(P>0.05)$. No statistical differences were found in the index of condition between the groups in each stream $(P>0.05)$.

The three sib-groups differed significantly in their length (Kruskal-Wallis test, $P<0.001)$. The frequencies of precocious males differed significantly in the examined groups (chi-squared test, table $3 \times 2, P<0.001)$. The differences between groups growing in Pniewa and Smerdnica, and Smerdnica and Trawna were significant (Fisher exact test, $2 \times 2$ tables, $P<$ $0.005, P<0.001$, respectively); the differences between groups growing in Pniewa and Trawna was not significant (Fisher exact test, $2 \times 2$ tables, $P>0.05$ ).

The frequencies of incomplete maturation in precocious males differed significantly in the examined groups (chi-squared test, table $3 \times 2, P<0.001$ and Fisher exact test, $2 \times 2$ tables $P<0.001$ ).

The sib-group of larger fish contained more precocious males, and the gonads of more precocious males underwent of complete maturation, compared to the sibgroup of smaller fish.

It seems that incomplete gonad maturation occurs at a smaller critical fish size than the complete form of gonad maturation. The incomplete form of gonad maturation is more frequent among smaller individuals and possibly in slow-growing groups of fish.

\section{DISCUSSION}

Body size of the smallest maturing sea trout males were close to the minimum body size attained by precocious individuals in related species. The precocious under-yearling and 2-year-old Atlantic salmon measured $6.0-7.0 \mathrm{~cm}[7,15,20]$ or were slightly longer than $7.0 \mathrm{~cm}[11,27]$; the under-yearling Caspian trout measured 6.4-7.0 $\mathrm{cm}$ [28] and the underyearling masu salmon were $7.0-8.0 \mathrm{~cm}$ long [14]. Among the sea trout examined in this study, even the smallest individuals were precocious. Consequently, no critical length necessary for precocious sexual maturation can be discerned in the sea trout studied; theoretically, all the individuals could be precocious as early as in their first year of life. Some authors reject the notion of the critical length being a prerequisite of precocious maturation [29], whereas Gall [30] stated that the critical length in faster-growing individuals is lower than that in the fish growing at a moderate rate. By Baum et al. [31] the size threshold above which parr matured depended on altitude, which could serve as a proxy for growth opportunity.

In the three sib-groups of the sea trout examined, the smallest precociously maturing individuals showed incomplete maturation. The smallest male $(7.1 \mathrm{~cm}$ fork length) revealed attempted maturation, while another small male $(7.9 \mathrm{~cm})$ showed partial maturation. The smallest males completely maturing measured $9.2 \mathrm{~cm}$ in fork length. The mean fork length of the individuals incompletely maturing in each of the three examined sibgroups was lower than that of the males 
showing complete maturation, but the differences were not significant. Most probably, for a gonad to completely mature, it is necessary that the fish attain, i.e., a critically larger body size. In the White Sea trout, Murza and Khristoforov [25] found, too, a slightly smaller body size in the males that showed attempted maturation, compared to the fish showing complete maturation.

The three sib-groups of examined males, harvested from different streams, differed significantly in their length. The larger, on the average sib-group, showed a higher proportion of precocious males and a lower percentage of individuals with incomplete gonad maturation. In the smallest, on the average sib-group, the fish featured the lowest number of males matured precociously and the gonads of all the males showed incomplete gonad maturation. However the studied groups were sibling and proportion of precocious males obtained could have been affected by genetic traits, since heritability of propensity for precocious maturation is relatively high [29,32-35], most probably gonad maturation is related to fish size and growth rate similarly as propensity for precocious maturation. It is likely that incomplete forms of gonad maturation are affected by low growth rate and small body size. On the contrary, defected (incomplete) maturation could not accelerate growth at a level as complete maturation $[32,36]$.

Besides heritability, the environmental factors influencing fish growth rate play a very important role in early triggering of the reproductive system as well $[12,29,30,37-41]$. It is not only the body size that is important in the reproductive function take-off. Fat deposits, too, may play a role in determining whether or not some vertebrates are ready to mature $[42,43]$. Some authors are of the opinion that only those fish that have accumulated suitable energy reserves $[12,19$,
44] or visceral fat $[45,46]$ will start maturing. According to Silverstein et al. [47] an effect in fat content is more distinct in smaller fish. Moreover, it is important that the fat be accumulated at an appropriate stage of development. For instance, the Atlantic salmon will re-mature only when fat reserves are replenished by the spring (May). Fat depletion lasting until May results in a failure to mature in that year [46].

When estimating the proportion of precocious males maturing in their first year of life, it is necessary to study histology due to the very high variability in the dynamics of the first sexual cycle, as exemplified by the sea trout examined and forms of incomplete gonad maturation. It is not enough to examine the gonad morphology and/or to induce spermation by abdominal massage, because in some of the incompletely maturing fish, spermatozoa do not move to the vas deferens $[20,21,24]$.

\section{REFERENCES}

[1] Zakes Z, Demska-Zakes K. Effect of diets on growth and reproductive development of juvenile pikeperch, Schizostedion lucioperca (L.), reared under intensive culture conditions. Aqua Res 1996, 27: 841-845.

[2] Dziewulska K, Domagała J. Testicular development in the sea trout (Salmo trutta morpha trutta L.) after sex differentiation, with a reference to precocious maturation. J Appl Ichthyol 2004, 20: 282-289.

[3] Adams CE, Huntingford FA. Growth, maturation and reproductive investment in Arctic charr. J Fish Biol 1997, 51: 750-759.

[4] Baglinière JL, Maisse G. Observations on precocious maturation and smoltification relationship in wild Atlantic salmon populations in Armorican Massif (France). Aquaculture 1985, 45: 249-263.

[5] Brannon E, Feldmann C, Donaldson L. University of Washington zero-age coho salmon smolt production. Aquaculture 1982, 28: $195-200$.

[6] Clarke WC, Blackburn J. Effect of growth on early sexual maturation in stream-type chinook salmon. Aquaculture 1994, 121: 95-103. 
[7] Dalley EL, Andrews CW, Green JM. Precocious male Atlantic salmon (Salmo salar) in insular Newfoundland. Can J Fish Aquati Sci 1983, 40: 647-652.

[8] Dellefors C, Faremo U. Early sexual maturation in males of wild sea trout, Salmo trutta L., inhibits smoltification. J Fish Biol 1988, 33: 741-749.

[9] Greenstreet SPR, Morgan RIG, Thorpe JE. Effect of stripping on the length, condition and gonadal state of mature male Altlantic salmon, Salmo salar L., parr during autumn and winter. J Fish Biol 1992, 41: 191-200.

[10] Leyzerovich KhA. O karlikovykh samtsakh pri zavodskom razvedenii atlantichieskogo lososya Salmo salar L. [On dwarfed males during artificial reproduction of the Atlantic salmon, Salmo salar L.]. Vop Ikhtiol 1973, 13: 460-470 (in Russian).

[11] Rowe DK, Thorpe JE. Differences in growth between maturing and non-maturing male Atlantic salmon, Salmo salar L., parr. J Fish Biol 1990, 36: 643-658.

[12] Silverstein JT, Hershberger WK. Precocious maturation in coho salmon (Oncorhynchus kisutch): Estimation of the additive genetic variance. J Heredity 1992, 83: 282-286.

[13] Skilbrei OT, Compensatory sea growth of male Atlantic salmon, Salmo salar L., which previously mature as parr. J Fish Biol 1990, 37: 425-435.

[14] Utoh H. Study of the mechanism of differentiation between the stream resident form and the seaward migratory form of masu salmon, Oncorhynchus masou (Brevoort). II. Growth and sexual maturity of precocious masu salmon parr (2). Bull Fac Fish Hokkaido Univ 1977, 28: 66-73 (in Japan).

[15] Utrilla CG, Lobòn-Cerviá J. Life-history patterns in a southern population of Atlantic salmon. J Fish Biol 1999, 55: 69-83.

[16] Dębowski P, Glogowski J, Dobosz S, Robak S. Gill $\mathrm{Na}^{+}-\mathrm{K}^{+}$ATPase activity and body silvering as indices of smoltification of hatchery-reared sea trout (Salmo trutta m. trutta L.). Arch Ryb Pol 1999, 7: 245-256.

[17] Dębowski P, Glogowski J, Robak S, Dobosz S. Smoltyfication of hatchery-reared atlantic salmon (Salmo salar L.) - indices and methods of estimation. Arch Ryb Pol 1999, 7: 267-279.

[18] Nicieza AG, Braña F, Toledo MM. Development of length-bimodality and smolting in wild stocks of Atlantic salmon,
Salmo salar L., under different growth conditions. J Fish Biol 1991, 38: 509-523.

[19] Bailey JK, Saunders RL, Buzeta MI Influence of parental smolt age and sea age on growth and smolting of hatchery-reared Atlantic salmon (Salmo salar) Can J Fish Aquati Sci 1980, 37: 1379-1386.

[20] Murza IG, Khristoforov OL. Spermatogenez i polovoy tsykl samtsov atlanticheskogo lososya Salmo salar L. 1. Stanovlenie reproduktivnoy funktsii i periodizatsia tsikla razvitia semennikov [Spermatogenesis and reproductive cycle of male Atlantic salmon, Salmo salar L. 1. Development of reproductive function and seasonality of testis development]. Sb Nautchnykh Trudov GosNIORKH 1983, 200: 50-73 (in Russian).

[21] Dziewulska K. Spermatogeneza młodziezy troci wedrownej (Salmo trutta m. trutta L.) Pomorza Zachodniego [Spermatogenesis in the sea trout (Salmo trutta m. trutta L.) parr in Western Pomerania]. $\mathrm{PhD}$ thesis, University of Szczecin, Szczecin 2001, p 102 (in Polish).

[22] Dziewulska K, Domagała J. Histology of salmonid testes during maturation. Reprod Biol 2003, 3: 47-61.

[23] Murza IG. Issledovanie razvitia semiennikov segoletok nevskogo lososya, vyrashchivaemykh pri razlichnykh temperaturnykh rezhimakh [A study on the testicular development in the young-of-the-year Neva salmon, grown at various temperatures]. Sb Nautchnykh Trudov GosNIORKH 1976, 112: 113-117 (in Russian).

[24] Murza IG, Khristoforov OL. Periodizatsia gametogeneza i shkaly zrelosti polovykh zhelyoz samok i samtsov kumzhi [Seasonality of gametogenesis and gonad maturity scales in female and male sea trout]. Sb Nautchnykh Trudov GosNIORKH 1984, 220: 19-41 (in Russian).

[25] Murza IG, Khristoforov OL. Dinamika polovogo sozrevania i nekatorye zakonomernosti formirovania slozhnoy struktury populatsiy kumzhi Salmo trutta L. iz vodoemov poberezhya Kandalakshskogo zaliva Belogo morya [Dynamics of sexual maturation and certain regularities in the formation of the complex population structure of sea trout, Salmo trutta L., in the Kandalaksha Bay (White Sea) coastal water bodies]. Sb Nautchnykh Trudov GosNIORKH 1984, 220: 41-86 (in Russian). 
[26] Dziewulska K, Domagała J. Differentiation of gonad maturation in sibing precocious males of the sea trout (Salmo trutta morpha trutta L.) in their first year of life. Aquaculture 2005, 250: 3-4, 713-725.

[27] Myers RA, Hutchings JA, Gibson RJ. Variation in male parr maturation within and among populations of Atlantic salmon, Salmo salar. Can J Aquat Sci 1986, 43: 1242-1248.

[28] Murza IG, Khristoforov OL. Gametogenez u kumzhi Salmo trutta m. lacustris L. I. Salmo trutta trutta L. nekototykh wodojemow Terskogo poberezh'ya Belogo moray [Gametogenesis in trout Salmo trutta m. lacustris L. and Salmo trutta trutta L. in some water bodies of the Tersk coast of the White Sea]. Sb Nautchnykh Trudov GosNIORCH 1981, 174: 34-53 (in Russian).

[29] Nævdal G. Genetic factors in connection with age maturation. Aquaculture 1983, 33: 97-106.

[30] Gall GAE. Genetics of fish: a summary of discussion. Aquaculture 1983, 33: 383-394.

[31] Baum D, Laughton R, Armstrong JD, Metcalfe NB. Altitudinal variation in the relationship between growth and maturation rate in salmon parr. J Anim Ecol 2004, 73: 253-260.

[32] Gjerde B. Response to individual selection for age at sexual maturity in Atlantic salmon. Aquaculture 1984, 38: 229-240.

[33] Iwamoto RN, Alexander BA, Hershberger WK. Genotypic and environmental effects on the incidence of sexual precocity in coho salmon (Oncorhynchus kisutch). Aquaculture 1984, 43: 105-121.

[34] Thorpe JE, Morgan RIG, Talbot C, Miles MS. Inheritance of developmental rates in atlantic salmon, Salmo salar L. Aquaculture 1983, 33: 119-128.

[35] Svedäng H. Genetic basis of life-history variation of dwarf and normal Arctic charr, Salvelinus alpinus (L.), in Stora Rösjön, central Sweden. J Fish Biol 1990, 36: 917-932.

[36] Berglund I, Mayer I, Borg B. Effect of sexual maturation, castration, and androgen implants on growth in one- and two-yearold parr in a Baltic Atlantic salmon (Salmo salar) stock. J Fish Biol 1992, 40: 281-292.
[37] Herbinger CM, Friars GW. Effects of winter temperature and feeding regime on the rate of early maturation in Atlantic salmon (Salmo salar) male parr. Aquaculture 1992, 101: 147-162.

[38] Murza IG, Khristoforov OL. Influence of different temperature regimes and sex steroid treatments on the rate of maturation and population structure in cultured Atlantic salmon. In: Svennnnevig N, Krogdahl A (Eds), International Conference Aquaculture Europe'95, Trondheim, Norway, European Aquaculture Society Special Publication No. 23, Gent, Belgium, 1995, pp 351-352.

[39] Saunders RL, Henderson EB. Effects of constant day length on sexual maturation and growth of Atlantic salmon (Salmo salar) parr. J Fish Res Board Can 1988, 45: 60-64.

[40] Schmidt SP, House EW. Precocious sexual maturation development in hatchery-reared and laboratory maintained male steelhead trout (Salmo gairdneri). J Fish Res Board Can 1979, 36: 90-93.

[41] Skilbrei OT. Importance of threshold length and photoperiod for the development of bimodal length-frequency distribution in Atlantic salmon (Salmo salar). Can J Fish Aquati Sci 1991, 48: 2163-2172.

[42] Derickson WK. Lipid storage and utilization in Reptiles. Am Zool 1976, 16: 711-723.

[43] Fitzpatrick LC. Life history patterns of storage and utilization of lipids for energy in Amphibians. Am Zool 1976, 16: 725-732.

[44] Saunders RL, Henderson EB, Glebe BD. Precocious sexual maturation and smoltification in male Atlantic salmon (Salmo salar). Aquaculture 1982, 28: 211-229.

[45] Herbinger CM, Newkirk GF. Sources of family variability for maturation incidence in cultivated Atlantic salmon. Aquaculture 1990, 85: 153-162.

[46] Rowe DK, Thorpe JE, Shanks AM. Role of fat stores in the maturation of male Atlantic salmon (Salmo salar) parr. Can J Fish Aquati Sci 1991, 48: 405-413.

[47] Silverstein JT, Shearer KD, Dickhoff WW, Plisetskaya EM. Effects of growth and fatness on sexual development of chinook salmon (Oncorhynchus tshawytscha) parr. Can J Fish Aquati Sci 1998, 55: 2376-2382. 